\title{
Role of temperature in growth, feeding, and vertical distribution of the mixotrophic chrysophyte Dinobryon
}

\author{
Adam W. Heinze ${ }^{1,2, *}$, Corinne L. Truesdale ${ }^{1}$, Sarah B. DeVaul ${ }^{1}$, Jonathan Swinden ${ }^{1}$, \\ Robert W. Sanders ${ }^{1}$ \\ ${ }^{1}$ Department of Biology, Temple University, Philadelphia, Pennsylvania 19122, USA \\ ${ }^{2}$ Present address: Alvernia University, 3104 Bernardine Hall, Reading, Pennsylvania 19607, USA
}

\begin{abstract}
Dinobryon spp. are common components of the phytoplankton in temperate lakes. While these chrysophytes link bacterial carbon as well as primary production to the larger food web, few studies have examined their vertical distribution over a season. Data were collected over a $2.5 \mathrm{yr}$ period in mesotrophic Lake Lacawac in eastern Pennsylvania (USA) to examine water column attributes relating to seasonality of the mixotrophic alga D. cylindricum, and specifically to address a hypothesis that abundance and vertical distribution in the genus are associated with temperature. This information was used to guide laboratory experiments examining temperature and light effects on growth, feeding, and vertical migration of cultured Dinobryon. Data from Lake Lacawac and the literature indicated that high abundances of Dinobryon were associated with a narrow range of temperature $\left(9-18^{\circ} \mathrm{C}\right)$ relative to temperatures where they were present $\left(3-26^{\circ} \mathrm{C}\right)$. High abundances of several species of Dynobryon were associated with this temperature range, and occurred from late winter to late spring, depending on latitude and depth in the water column. Although high Dinobryon abundances were not tied directly to levels of photosynthetically active radiation in Lake Lacawac, a UV-exclusion experiment in a nearby oligotrophic lake indicated a temperature-dependent negative effect of UV radiation. UV may limit the occurrence of Dinobryon populations in surface waters of clear oligotrophic lakes. Laboratory experiments showed that both light and temperature affected growth and feeding rates of Dinobryon, and that maximum feeding and growth rates occurred within the temperature range where high Dinobryon abundances were observed in field studies.
\end{abstract}

KEY WORDS: Phytoplankton · Lake bloom · Succession · Ultraviolet radiation · Seasonality

\section{INTRODUCTION}

Chrysophytes in the genus Dinobryon are a common and often numerically important component of the phytoplankton in temperate lakes (Ostrofsky \& Duthie 1975, Lehman 1976, Siver \& Chock 1986, Bird \& Kalff 1987, Hitchman \& Jones 2000, Watson et al. 2001, Tadonléké et al. 2002, Kamjunke et al. 2007). With a potential to temporarily dominate phytoplankton biomass, they play several key roles in these systems. For example, Dinobryon species are mixotrophic-combining phagotrophy with phototrophy - and in Lac Cromwell, Quebec (Canada), they were shown to ingest more bacteria than did crustaceans, rotifers, and ciliates combined (Bird \& Kalff 1986). Likewise, in Lake Oglethorpe, Georgia (USA), Dinobryon, along with other mixotrophs, were frequently the dominant bactivores (Sanders et al. 1989). Dinobryon are consumed by copepods and small Daphnia, and can be a major food of large-bodied cladoceran zooplankton (Tappa 1965, Sanders \& Porter 1990, Sommer et al. 
2003). Thus, Dinobryon spp. link bacterial carbon as well as primary production to the larger food web. In addition, Dinobryon spp. can cause water treatment problems (Watson et al. 2001, Satchwill et al. 2007).

Seasonality in the genus is well known and has been attributed to a variety of factors including light, potassium toxicity, iron availability, predation, and an inability to compete with other phytoplankton during periods of high nutrient concentrations (Lehman 1976, Siver \& Chock 1986, Dokulil \& Skolaut 1991, Veen 1991). The degree to which mixotrophy is related to the vertical and seasonal distribution of Dinobryon is uncertain, but the ability to incorporate limiting nutrients via ingestion of bacteria may well contribute to its commonness in oligotrophic systems and to its ability to reach peak abundances at depths where attenuation has reduced light to very low levels (Siver \& Chock 1986, Eloranta 1989, Veen 1991, Caron et al. 1993, Kamjunke et al. 2007).

None of the factors proposed to affect the seasonal distribution of Dinobryon are mutually exclusive, but an overall importance of temperature is suggested by peak seasonal abundances recorded during late winter in semi-tropical climate, spring in temperate, and summer in colder climates (e.g. Flint 1938, Siver \& Chock 1986, Eloranta 1989, Sanders et al. 1989). Furthermore, thermotaxic responses in Dinobryon were observed in laboratory experiments. D. sertularia responded with slowed swimming and increased turning at 'preferred' temperatures in horizontal temperature gradients (Clegg et al. 2003), and Dinobryon sp. migrated to depths with an intermediate temperature range in a vertical gradient in which light and nutrients were constant (Heinze \& Sanders 2009). Nevertheless, the role of temperature in the vertical/depth distribution of the genus in lakes is essentially unexplored. In the present study, field data collected from a mesotrophic lake over approximately $2.5 \mathrm{yr}$, data from the literature, and a series of laboratory experiments were combined to examine how physical attributes of the water column related to the seasonality of Dinobryon, and specifically to address the hypothesis that high abundance and vertical distribution are associated with temperature and light.

\section{MATERIALS AND METHODS}

\section{Field site and sampling}

Lake Lacawac $\left(41^{\circ} 22.9^{\prime} \mathrm{N}, 75^{\circ} 17.5^{\prime} \mathrm{W}\right.$; maximum $\operatorname{depth}\left[z_{\max }\right]=12 \mathrm{~m}$ ) is a mesotrophic ice-scour glacial lake located in the Pocono Mountains of northeastern Pennsylvania, USA. The 21 ha lake and its watershed remain undeveloped and are protected by the Lacawac Sanctuary Foundation. It is a softwater, slightly acidic lake with little buffering capacity, and total dissolved phosphorus is typically $<5 \mu \mathrm{g} \mathrm{l^{-1 }}$ in the photic zone (R. E. Moeller \& C. E. Williamson unpubl. data). The phytoplankton community is seasonally dominated by chrysophycean algae, including Dinobryon (Siver \& Chock 1986).

Water was collected at $1 \mathrm{~m}$ intervals from the surface to $11 \mathrm{~m}$ using a Van Dorn sampler. Sampling spanned the period from April 2005 to September 2007 (Table 1), with collections at a single station in the deepest part of the lake until March 2007 when 3 additional stations were added along a cross-lake transect. These additional stations were sampled at $1,3,6$, and $9 \mathrm{~m}$ depths. For plankton enumeration, $125 \mathrm{ml}$ subsamples from each depth were fixed with Lugol's iodine (3\% final concentration).

Secchi disk depth was determined at each station, and temperature and oxygen concentrations were measured using a YSI model 58 meter. Light attenu-

Table 1. Secchi disk depths, mean water temperatures, and maximum Dinobryon cylindricum abundances in Lake Lacawac, Pennsylvania, USA

\begin{tabular}{|lccccc|}
\hline Date & $\begin{array}{c}\text { Light } \\
\text { atten- } \\
\text { uation } \\
\left(k, \mathrm{~m}^{-1}\right)\end{array}$ & $\begin{array}{c}\text { Secchi } \\
\text { disk } \\
\text { depth } \\
(\mathrm{m})\end{array}$ & $\begin{array}{c}\text { Depth } \\
\text { of max. } \\
\text { Dinobryon } \\
\text { abund. }(\mathrm{m})\end{array}$ & $\begin{array}{c}\text { Max. } \\
\text { Dinobryon } \\
\text { abund. } \\
\left(\text { no. ml }{ }^{-1}\right)\end{array}$ & $\begin{array}{c}\text { Temp. } \\
\text { at max. } \\
\text { Dinobryon } \\
\text { abund. }\left({ }^{\circ} \mathrm{C}\right)\end{array}$ \\
\hline 9 Apr 2005 & 0.61 & 2.8 & 3 & 2 & 6.5 \\
13 May 2005 & 0.63 & 2.7 & 4 & 1677 & 11.2 \\
13 Jun 2005 & 0.65 & 2.6 & 4 & 4284 & 14.6 \\
11 Jul 2005 & - & - & 9 & 122 & 5.8 \\
2 Aug 2005 & 0.85 & 2.0 & 4 & 11 & 19.1 \\
1 Oct 2005 & 0.57 & 3.0 & 1 & 37 & 17.7 \\
3 Nov 2005 & 0.68 & 2.5 & 4 & 18 & 9.1 \\
21 Jan 2006 & - & - & 1 & 70 & 2.9 \\
22 Feb 2006 & 0.77 & 2.2 & 1 & 395 & 4.1 \\
23 Mar 2006 & 0.85 & 2.0 & 7 & 450 & 3.0 \\
20 Apr 2006 & 0.65 & 2.6 & 1 & 4608 & 13.7 \\
13 May 2006 & 0.68 & 2.5 & 1 & 4488 & 18.2 \\
22 Jun 2006 & 0.74 & 2.3 & 6 & 373 & 9.3 \\
17 Jul 2006 & 0.74 & 2.3 & 4 & 40 & 15.8 \\
23 Mar 2007 & 0.57 & 3.0 & 5 & 2 & 4.2 \\
13 Apr 2007 & 0.52 & 3.3 & 10 & 95 & 4.7 \\
5 May 2007 & 0.40 & 4.3 & 1 & 6 & 14.5 \\
22 Jun 2007 & 0.38 & 4.5 & 2 & 42 & 22.8 \\
20 Jul 2007 & 0.40 & 4.3 & 5 & 81 & 16.3 \\
\hline
\end{tabular}


ation $\left(k_{;} \mathrm{m}^{-1}\right)$ was estimated from Secchi measurements (1.7/Secchi depth) for all dates sampled, and was compared to light measured at depth using a BIC profiling radiometer (Biosphericals Instruments) on May 13, 2005. Data on hourly and daily photosynthetically active radiation (PAR) insolation at Lake Lacawac (Hargreaves 2007) was used with attenuation calculations from Secchi readings to determine light levels at depth for peak Dinobryon abundances.

\section{Microscopic enumeration}

For field experiments, fixed samples were concentrated by settling in $100 \mathrm{ml}$ graduated cylinders for $\geq 24 \mathrm{~h}$, after which $90 \mathrm{ml}$ were removed by aspiration; the exact volume of the remaining sample was measured to determine a concentration factor. Dinobryon were enumerated in a subsample from transects covering 20 to $100 \%$ of a Sedgewick-Rafter chamber at $250 \times$ magnification. For laboratory experiments (below), the concentrating step was eliminated.

\section{Response to UVR exposure and temperature}

Ultraviolet radiation (UVR) and temperature were experimentally manipulated over a $10 \mathrm{~d}$ period beginning on 10 April 2006 in Lake Giles, an oligotrophic system approximately $16 \mathrm{~km}$ due east of Lake Lacawac. Although UVR is unlikely to have large effects on Dinobryon in Lake Lacawac due to strong absorption of UVR in the top few centimeters, the data are included here for their relevance to vertical distribution and interaction with temperature across lake systems. An integrated sample (0 to $3 \mathrm{~m}$ ) was passed through a $60 \mu \mathrm{m}$ screen to remove zooplankton, placed in UV-transparent 3.81 Bitran ${ }^{\circledR}$ $\mathrm{S}$-series bags (Com-Pac International), and maintained in temperature-controlled incubators on the lake shore in natural sunlight. Replicates were incubated under either UV-transparent (OP-4) or UVblocking (OP-2) Acrylite ${ }^{\circledR}$ (Evonik Industries). In one set of incubations, the samples were maintained at the initial lake temperature $\left(5.5^{\circ} \mathrm{C}\right)$, while for a second set, the temperature was gradually raised $10^{\circ} \mathrm{C}$ from ambient lake temperature over a $3 \mathrm{~d}$ period and samples incubated for a further $7 \mathrm{~d}$ at the elevated temperature. Dinobryon, and for this experiment other phytoplankton, were enumerated as described above. For comparative purposes, algal abundances were converted to biovolume using dimensions of representative cells matched to geometric shapes (Olenina et al. 2006).

\section{Culture conditions for laboratory experiments}

The Dinobryon sp. used in all laboratory experiments was obtained from the University of Toronto Culture Collection (UTCC no. 392; UTCC is now the Canadian Phycological Culture Centre). This strain from UTCC originated from the University of Texas Culture Collection (UTEX strain no. 2267). Cells were maintained under a $12: 12 \mathrm{~h}$ light:dark cycle at $18^{\circ} \mathrm{C}$ in DY-IV medium (Sanders et al. 2001). Light was supplied by Cool-White fluorescent lamps (PAR: 25$67 \mu \mathrm{M} \mathrm{m}^{-2} \mathrm{~s}^{-1}$ ).

\section{Temperature effects on growth and feeding: laboratory experiments}

Experiments were performed in a walk-in cold room $\left(13^{\circ} \mathrm{C}\right)$ with 3 replicates per treatment, and temperature was maintained in insulated water baths using Jäger model 3602 submersible heaters (Eheim). Culture flasks with $100 \mathrm{ml}$ of Dinobryon culture in dilute (20\%) DY-IV medium at $18^{\circ} \mathrm{C}$ were immersed in the water baths held at $13^{\circ}, 15^{\circ}, 17^{\circ}, 19^{\circ}$, and $21^{\circ} \mathrm{C}$ without acclimation. Cool-White fluorescent lamps provided constant illumination at $67 \mu \mathrm{M} \mathrm{m}^{-2} \mathrm{~s}^{-1}$. Light intensity was measured using Biospherical Instruments model QSL-100 Quantum Irradiance. Dinobryon were sampled daily, preserved with Lugol's iodine, and enumerated as above.

A second series of temperature experiments was performed to examine whether gradual temperature shifts $\left(2^{\circ} \mathrm{C} \mathrm{d}^{-1}\right)$ had similar effects as the acute shift, and to determine rates of bacterivory at different temperatures and light levels. These experiments were run under continuous light in a temperaturecontrolled incubator (Precision). Two light treatments were used for each temperature, with PAR irradiance of 25 and $67 \mu \mathrm{M} \mathrm{m}^{-2} \mathrm{~s}^{-1}$. Treatments had 3 and 5 replicates at the low and high irradiance, respectively.

After acclimation, feeding experiments used subsamples from each temperature-light treatment during mid-exponential growth. Fluorescent polycarbonate microspheres $(0.6 \mu \mathrm{m}$, Polysciences) were added at $\sim 20 \%$ bacterial abundance. Subsamples were fixed immediately after particle addition (T0) and at 30 min using a Lugol's / formaldehyde / $\mathrm{Na}_{2} \mathrm{~S}_{2} \mathrm{O}_{3}$ method to prevent egestion (Sherr \& Sherr 1993). Ingested microspheres were counted using 
epifluorescence on a Zeiss Axiovert microscope, and rates of bacterivory were determined from the ratio of added microspheres to bacterial abundance (Sanders et al. 1989). Preliminary experiments indicated linear uptake by Dinobryon for > $30 \mathrm{~min}$.

\section{Synthesis and data analysis}

Data on vertical distribution of Dinobryon and temperature changes with depth in Lake Lacawac were combined with similar data from the literature (Flint 1938, Bird \& Kalff 1987, Hitchman \& Jones 2000, Kamjunke et al. 2007, R. W. Sanders unpubl. data) to examine patterns across geographical distance and lake type. Abundances were converted to a percentage of maximum observed for each study for comparison. Statistical analyses, including ANOVA, Pearson 2-way chi-squared, and Spearman's rho tests, were performed using SPSS 15.0. For Pearson 2-way chi-squared test, data were grouped into 3 equal temperature ranges: $0^{\circ}-9.2^{\circ}, 9.3^{\circ}-18.3^{\circ}$, and $18.4^{\circ}-27.5^{\circ} \mathrm{C}$. The corresponding groups for abundance were $0,1-350$, and 351-4750 cells $\mathrm{ml}^{-1}$, corresponding to absence, moderate abundances, and bloom condition. The 350 cells $\mathrm{ml}^{-1}$ boundary level was chosen because abundances rarely exceeded that number except at times that a bloom occurred at some depth. Contour plots were generated using MATLAB (Mathworks).

\section{RESULTS}

\section{Environmental variables and seasonal distribution of Dinobryon in Lake Lacawac}

Lake Lacawac had strong temperature stratification in summer, cooling and mixing through autumn and winter, with subsequent spring warming of surface waters as daily insolation increased (Fig. 1A). Minimum and maximum incident daily PAR during the study period were 0.5 and $62.8 \mathrm{M} \mathrm{m}^{-2} \mathrm{~d}^{-1}$ on $4 \mathrm{De}$ cember and 23 June 2005, respectively (Fig. 2). Light attenuation for PAR calculated from Secchi depth and the BIC radiometer in Lake Lacawac had good agreement (0.630 and 0.610, respectively, in May 2005), suggesting that the Secchi depth was an adequate indicator of light attenuation. Subsequent comparisons between the Secchi and a LI-COR LI-250A meter with LI-193 quantum sensor also showed good agreement (S. B. DeVaul unpubl. data). The BIC radiometer also measured penetration of UV-A (380 nm) and UV$\mathrm{B}(305 \mathrm{~nm})$ radiation. The depths of $1 \%$ of surface irradiance for PAR, UV-A, and UV-B in May 2005 were $4.4,0.75$, and $0.23 \mathrm{~m}$, respectively. Light attenuation showed no clear seasonal pattern during the study, but was distinctly lower in 2007 than in the previous 2 yr (Table 1), indicating increased water clarity at the end of the study period.

During the 29 mo sampling period, Dinobryon cylindricum showed late spring population peaks,
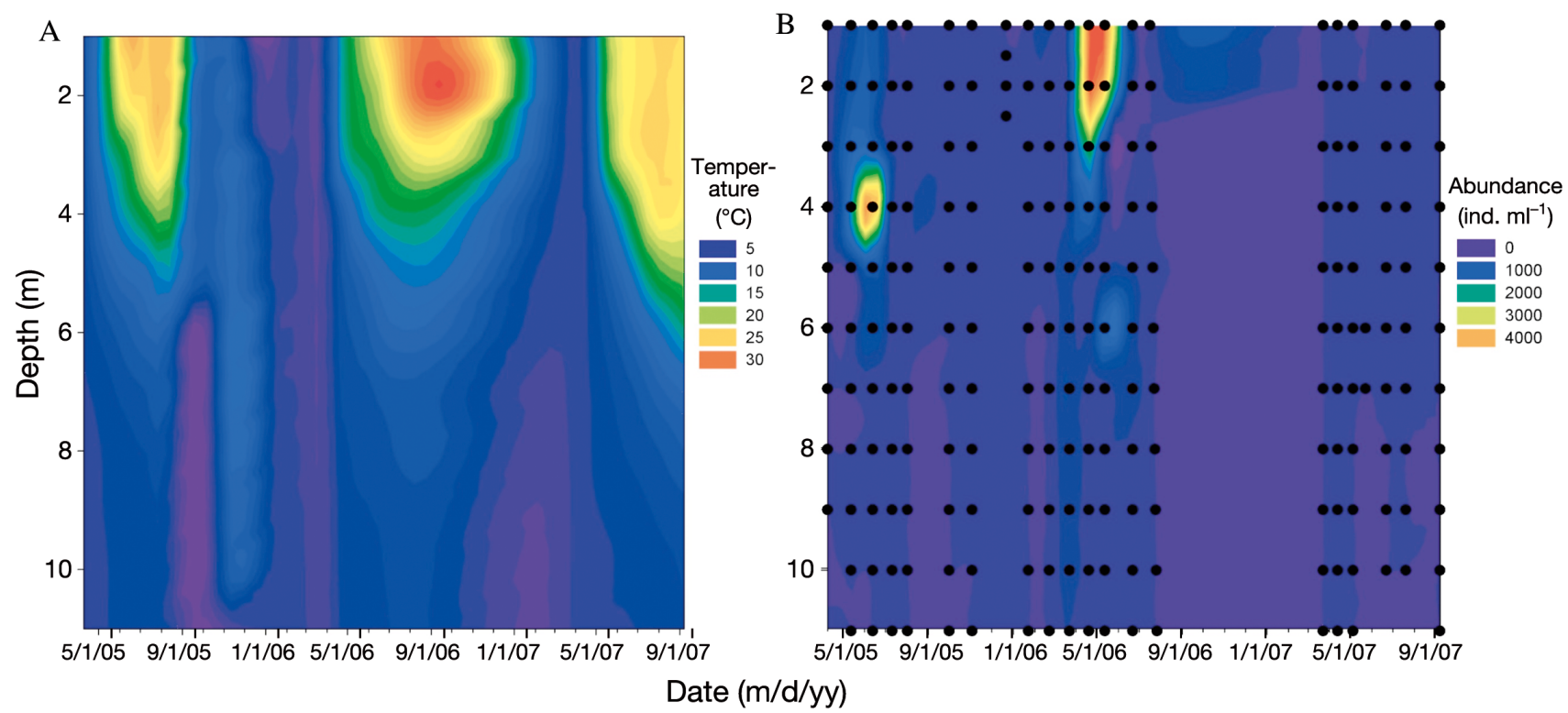

Fig. 1. Contour plots of (A) temperature and (B) Dinobryon spp. abundance/distribution in Lake Lacawac, Pennsylvania, USA, from May 2005 through September 2007. Black dots indicate dates and depths of sampling. The color keys for both panels represent a continuum from 0 (magenta) to the highest number recorded (bright orange). Note that for the purpose of constructing a continuum, periods not sampled were represented as zeros 


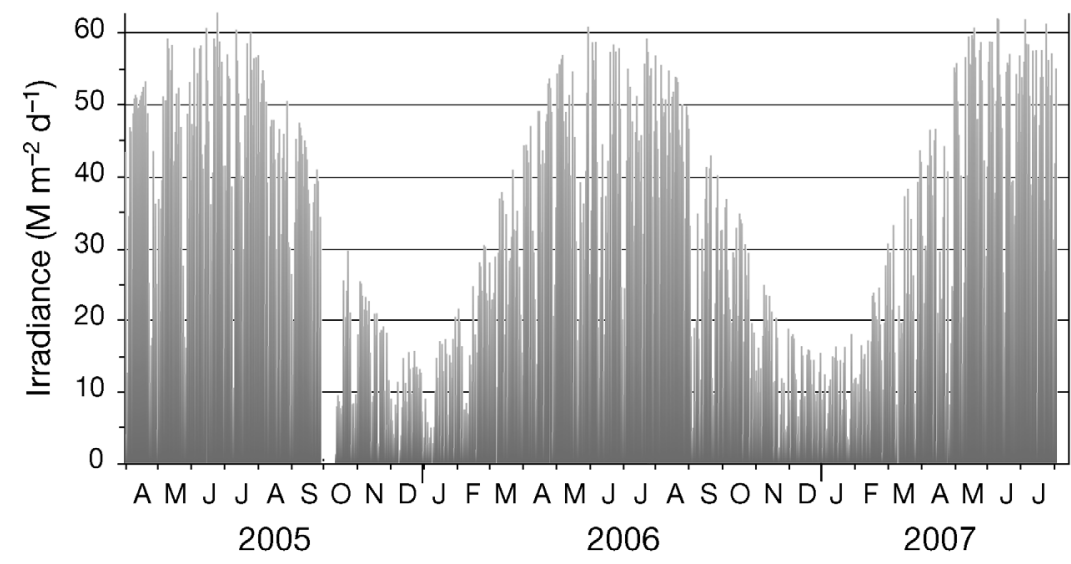

Fig. 2. Summed daily photosynthetically active radiation (PAR) irradiance during the study period plotted from weather station data collected at Lake Lacawac (Hargreaves 2007).

but abundances were close to the level of detection during much of the sampling period (Table 1). Occasional occurences of $D$. bavaricum, also close to the level of detection, were noted. Maximum annual abundances of $D$. cylindricum occurred at a depth of $4 \mathrm{~m}$ in June 2005 (4284 cells ml ${ }^{-1}$ ) and in a broader water stratum between 1 and $3 \mathrm{~m}$ in April 2006 $\left(\sim 4600\right.$ cells ml$\left.~^{-1}\right)$ near the onset of stratification (Fig. 1). In spring of 2007, the Dinobryon population increased relative to winter abundances, but populations as large as those in the previous $2 \mathrm{yr}$ were not observed (Fig. 1, Table 1).

On the days of maximum Dinobryon sp. abundance in 2005 and 2006, the daily surface irradiance was similar, 60.6 and $52.3 \mathrm{M} \mathrm{m}^{-2} \mathrm{~d}^{-1}$ (Fig. 2), as was the average PAR for the week prior to these abundance peaks (43.7 and $42.3 \mathrm{M} \mathrm{m}^{-2} \mathrm{~d}^{-1}$; Hargreaves 2007). However, the depths of maximum Dinobryon abundance (4 and $1 \mathrm{~m}$, respectively, Table 1), and light intensities at those

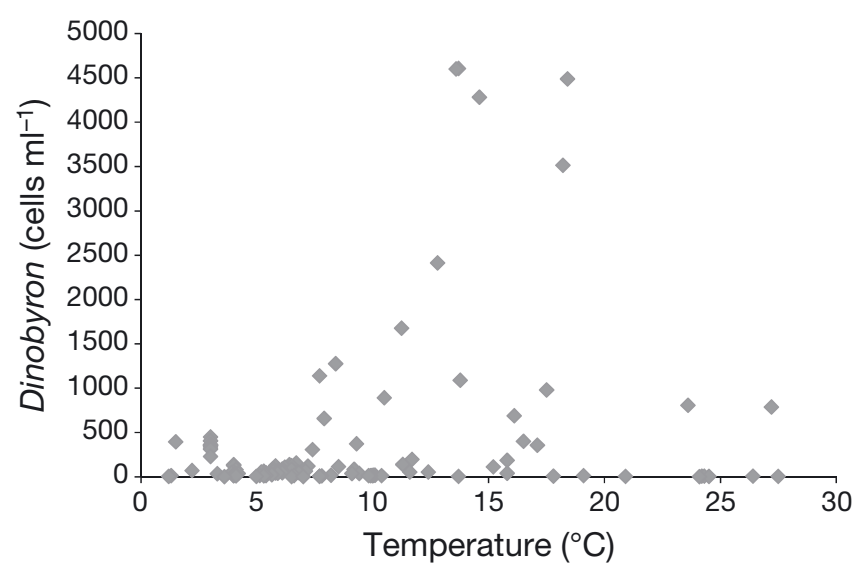

Fig. 3. Dinobryon cylindricum. Abundance versus temperature for all samples (dates and depths) when Dinobryon were present in the water column depths at the time of sampling (144 and $868 \mu \mathrm{M} \mathrm{m}^{-2} \mathrm{~s}^{-1}$ ), were considerably different. Conversely, temperatures at those depths were between $13^{\circ}$ and $15^{\circ} \mathrm{C}$. In 2006, high abundances observed in April were maintained through May at the same depth, although the water warmed to $18^{\circ} \mathrm{C}$ (Table 1) and average surface irradiance for the week prior to sampling in May 2006 was only $39.2 \mathrm{M} \mathrm{m}^{-2} \mathrm{~d}^{-1}$. In both 2005 and 2006, Dinobryon were virtually absent from the epilimnion once the water reached $20^{\circ} \mathrm{C}$.

Dinobryon abundance was not normally distributed, and a non-parametric Spearman's rho indicated a negative correlation between temperature and Dinobryon for time periods when the alga was present $(\mathrm{p}<$ 0.009). However, plotting Dinobryon abundance versus temperature for all dates and depths where the species was observed indicated that the highest abundances were recorded at intermediate temperatures (between $13^{\circ}$ and $18^{\circ} \mathrm{C}_{i}$ Fig. 3). The hypothesis that highest abundances (blooms) were found within an intermediate temperature range was tested with a 2-way chi-squared test of temperature to Dinobryon cells $\mathrm{ml}^{-1}$ for all the samples in the Lake Lacawac study. The null hypothesis of no relationship between the abundance values at different temperature ranges was rejected ( $p<0.001,2$-sided); the highest abundances occurred significantly more frequently (nearly 3 times greater than predicted) when temperatures were within the range of $9.3^{\circ}$ to $18.3^{\circ} \mathrm{C}$ (Table 2). Over the whole period of observation, abundances over 1000 Dinobryon $\mathrm{ml}^{-1}$ were observed only at temperatures between $11^{\circ}$ and $18.2^{\circ} \mathrm{C}$

Table 2. Two-way chi-squared test for temperature range and Dinobryon cylindricum abundances from all sampling dates and depths at Lake Lacawac. Pearson chi-squared = 22.722, 4 df. Occurrences were significantly higher or lower than expected $\left({ }^{*} p<0.001\right)$ only in the temperature range of 9.3 to $18.2^{\circ} \mathrm{C}$

\begin{tabular}{|lcccc|}
\hline \multirow{2}{*}{$\begin{array}{l}\text { Dinobryon } \\
\text { abundance } \\
\left(\text { cells } \mathrm{ml}^{-1} \text { ) }\right.\end{array}$} & & \multicolumn{4}{c|}{ Temperature range $\left({ }^{\circ} \mathrm{C}\right)$} \\
\hline 0 & $0-9.2$ & $9.3-18.2$ & $18.3-27.5$ \\
& Expected & 50.5 & 14.5 & 8 \\
$>0$ to 358 & Actual & 52 & 15 & 6 \\
& Expected & 96.9 & 27.8 & 15.4 \\
359 to 4700 & Actual & 103 & $19^{*}$ & 18 \\
& Expected & 16.6 & 4.8 & 2.6 \\
& Actual & 9 & $13^{*}$ & 2 \\
\hline
\end{tabular}




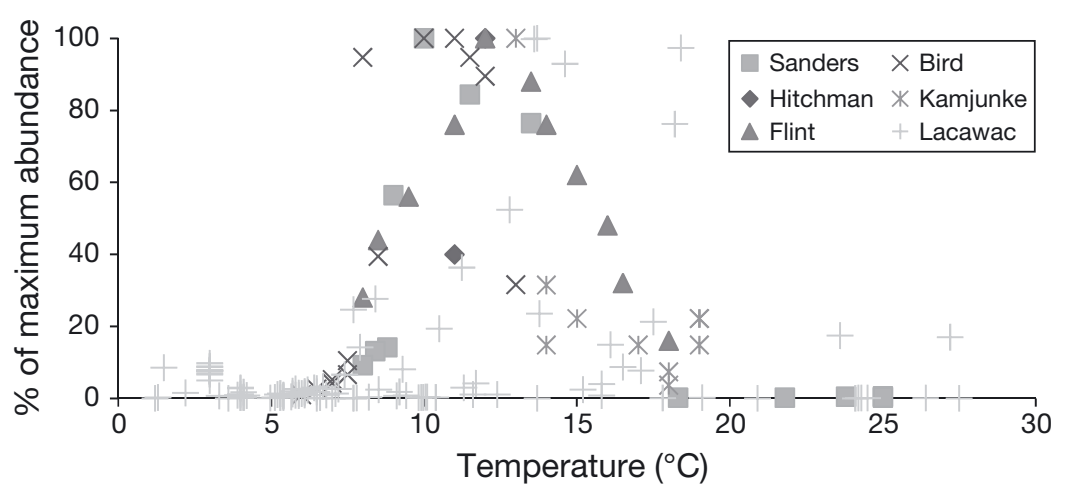

Fig. 4. Dinobryon spp. Abundance versus temperature for studies in several lakes. For each study, abundance data were converted to percent of the maximum for the entire observation period. All depths, including samples where Dinobryon were not present, were included. Data are from this study (Lacawac), Lake Oglethorpe, Georgia, USA (R. W. Sanders unpubl. data), and the literature (Flint 1938, Bird \& Kalff 1987, Hitchman \& Jones 2000, Kamjunke et al. 2007)

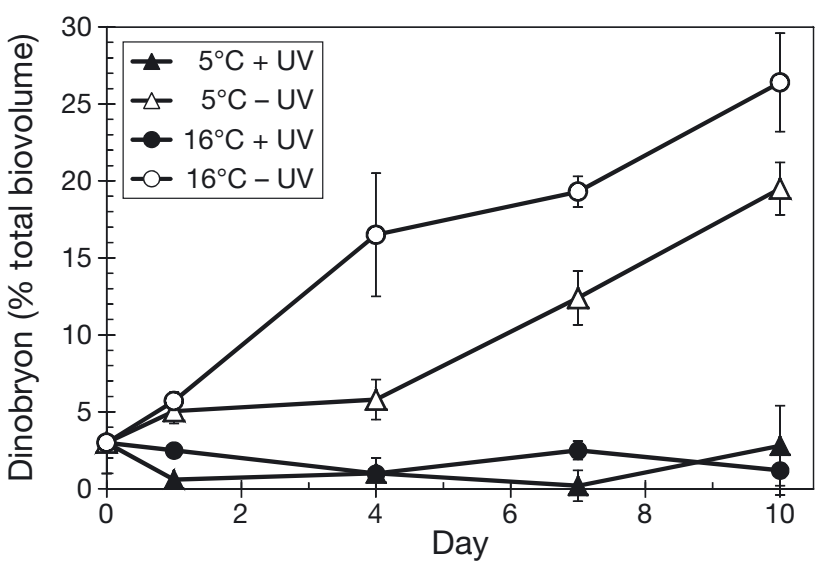

Fig. 5. Dinobryon cylindricum. Dinobryon as a percentage of total algal biovolume (mean $\pm \mathrm{SE}$ ) determined over time in a temperature shift and UV protection experiment

(Fig. 1, Table 1). When data on Dinobryon abundance and temperature at depth for several lakes were combined, the pattern observed in Lake Lacawac remained (Fig. 4). Most of the population during a given study was found at depths where water temperature was between $7^{\circ}$ and $17^{\circ} \mathrm{C}$, further suggesting a 'preferred' intermediate range of temperature in the vertical (and seasonal) distribution of Dinobryon.

\section{Dinobryon responses to natural UVR and changing temperature}

UVR attenuates rapidly in the water column of Lake Lacawac (see above), but can penetrate to considerable depth in clear lakes. When UV wave- lengths were blocked, Dinobryon incubated at the surface of oligotrophic Lake Giles had growth rates of 0.18 and $0.24 \mathrm{~d}^{-1}$ over $10 \mathrm{~d}$ when kept at $5.5^{\circ} \mathrm{C}$ or warmed to $16^{\circ} \mathrm{C}$, respectively. Dinobryon population biovolume increased from $<5 \%$ of total phytoplankton biovolume to approximately 15 and $25 \%$ at the cold and warm temperatures, respectively (Fig. 5). In the presence of full spectrum sunlight, Dinobryon abundance declined rapidly, from 50 to $4-12$ cells $\mathrm{ml}^{-1}$ and remained low to undetectable in all replicates. A 2-way ANOVA showed strong negative correlation of UVR and population growth for Dinobryon $(\mathrm{p}<0.001)$. The total biovolume of phytoplankton also declined in the treatments exposed to UVR, reflecting the generally negative effect of natural surface levels of UV on the whole phytoplankton community, and not solely on Dinobryon.

\section{Temperature, growth, and feeding in the laboratory}

Under high light $\left(67 \mu \mathrm{M} \mathrm{m}^{-2} \mathrm{~s}^{-1}\right)$ with no acclimation to temperature, Dinobryon sp. population growth rates $\left(\sim 0.21 \mathrm{~d}^{-1}\right)$ were similar to acclimated at $\leq 17^{\circ} \mathrm{C}$; growth was slower at $19^{\circ} \mathrm{C}$ and negative at $\geq 21^{\circ} \mathrm{C}$ (Fig. 6a). With a $5 \mathrm{~d}$ acclimation period to temperature and high light, growth rate increased $(0.15$ to $0.31 \mathrm{~d}^{-1}$ ) as incubation temperature increased from $4^{\circ}$ to $16^{\circ} \mathrm{C}$, and was lowest at $20^{\circ} \mathrm{C}$ (Fig. 6b). With acclimation and lower light $\left(25 \mu \mathrm{M} \mathrm{m}^{-2} \mathrm{~s}^{-1}\right)$, growth followed the same trend as at higher light levels except at about half the rate for temperatures between $4^{\circ}$ and $16^{\circ} \mathrm{C}$; population size declined slightly at $20^{\circ} \mathrm{C}$ (Fig. 6c). Bacterivory by Dinobryon during these experiments was significantly greater in low light than in high light, and occurred at a significantly greater rate at $12^{\circ} \mathrm{C}$ than at higher or lower temperatures for both light levels (Fig. 7). Minimum feeding rates were recorded in high light at the extremes of the temperature range tested.

\section{DISCUSSION}

Like other photosynthetic plankton, Dinobryon increase in abundance as day length, light intensity, 


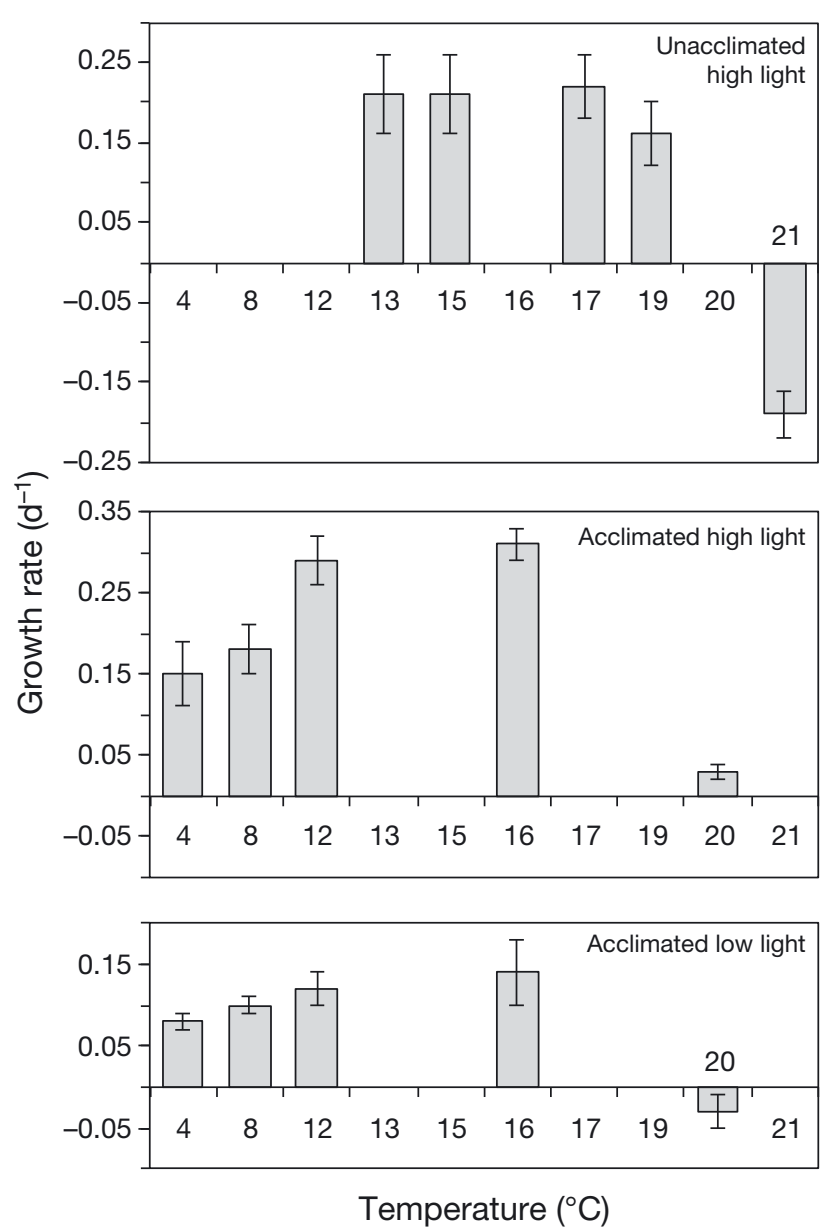

Fig. 6. Dinobryon sp. Growth rates (mean $\pm \mathrm{SE}$ ) at different temperatures, acclimation periods, and irradiances

and surface temperatures increase in the spring (Fig. 1; Siver \& Chock 1986, Eloranta 1989). Several non-exclusive environmental factors, including nutrients, light, and predation, have been linked to the seasonal dominance and decline of the genus (Lehman 1976, Siver \& Chock 1986, Dokulil \& Skolaut 1991, Veen 1991), but factors affecting vertical population peaks have received less attention. Using field and laboratory experiments, coupled with an examination of literature data, this study supports the premise that light and temperature interact to delimit a spatial (depth) / temporal niche where Dinobryon will bloom.

As mixotrophs, Dinobryon are not dependent on photosynthesis as their sole source of carbon, but laboratory evidence suggests that they are obligate phototrophs that cannot survive long periods in the dark (Caron et al. 1993). During periods of high abundance, the photic zone depth $(1 \%$ of surface irradiance) in Lake Lacawac was approximately $4.5 \mathrm{~m}$; below $5 \mathrm{~m}$, plankton would experience nearly com-

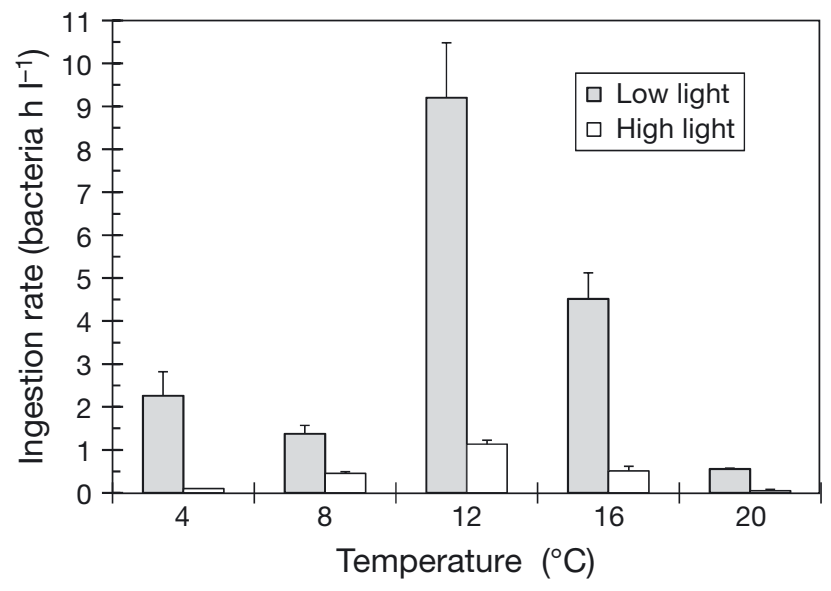

Fig. 7. Dinobryon sp. Rates of bacterivory at different temperatures and light intensities $( \pm \mathrm{SE})$. Shaded and white bars are experiments run with photosynthetically active radiation (PAR) light intensities of 25 and $67 \mu \mathrm{M} \mathrm{m}^{-2} \mathrm{~s}^{-1}$, respectively

plete darkness. Dinobryon were rarely found below $4 \mathrm{~m}$ in our study, suggesting that attenuation of PAR did set a maximum depth limit to their vertical distribution in this lake. However, no statistically significant relationship was noted for photic zone depth and Dinobryon abundance, and PAR did not appear to be the single critical component driving vertical distribution in the water column of Lake Lacawac.

Temperature was predictive of high abundances of Dinobryon in Lake Lacawac (Table 2). The 2 main seasonal peaks of Dinobryon abundance observed during our study occurred during late spring in 2005 and 2006, but with maximum abundances at different depths (Fig. 1, Table 1). Light intensities at those depths were 144 and $868 \mu \mathrm{M} \mathrm{m}^{-2} \mathrm{~s}^{-1}$ at the time of sampling in 2005 and 2006, respectively, while temperatures were $14.6^{\circ}$ and $13.6^{\circ} \mathrm{C}$, and overall PAR fluxes during the week prior to each bloom were similar. Furthermore, Dinobryon are active swimmers and will migrate in response to temperature in the absence of light and nutrient gradients (Clegg et al. 2003, Heinze \& Sanders 2009). Dinobryon has a broad range of temperature in which it survives (Table 1). Eloranta (1989) reported abundances for 8 species of Dinobryon from hundreds of Finnish lakes over many years and found that all 8 species were present at temperatures ranging from $<1^{\circ}$ to $22^{\circ} \mathrm{C}$. However, the high growth rates that lead to blooms of Dinobryon are less likely when temperatures are at the extremes of this range. Butterwick et al. (2005) found that $D$. divergens had maximum growth at an intermediate temperature $\left(17^{\circ} \mathrm{C}\right)$ when light and nutrients were not limiting, which agrees with our observations of maximum growth and grazing at an 
intermediate temperature for Dinobryon sp. (Fig. 6). The trend for maximum abundance at intermediate temperatures observed in Lake Lacawac was also evident in 5 other lakes (Fig. 4). These data were collected in lakes with maximum depths ranging from 8 to $>250 \mathrm{~m}$ that were distributed in the US, Canada, Europe, and New Zealand, and with different species of Dinobryon dominating. Together, these observations strongly support the inference that temperature has an important role in the occurrence of Dinobryon blooms and in structuring their vertical distribution.

It is unlikely that the UV component of the solar spectrum contributed much to inhibition of Dinobryon in Lake Lacawac because it attenuates rapidly there (Williamson et al. 2001). However, UVR may constrain Dinobryon to deeper water in oligotrophic lakes (such as Lake Giles) that are more transparent to UVR. Depending on temperature, Dinobryon may have a competitive advantage at the subsurface light levels in oligotrophic lakes; when UVR was blocked, Dinobryon populations increased in both absolute and relative abundance to other phytoplankton (Fig. 5). Dinobryon were more competitive at $16^{\circ} \mathrm{C}$, which is within the temperature range of maximum growth (Fig. 6b).

The lack of a Dinobryon bloom in Lake Lacawac during 2007 (Fig. 1, Table 1) was unexpected. Sampling was temporarily suspended during winter that year and an early bloom could have been missed. However, such early blooms have not been previously observed. Berninger et al. (1992) observed bacterivory by Dinobryon in Lake Lacawac during late February, but abundance of total mixotrophs (including Dinobryon, but dominated by other nanoflagellates) was only between 400 and 1100 cells $\mathrm{ml}^{-1}$. Siver \& Chock (1986) reported a bloom in Lake Lacawac in March 1981, but relatively high abundances (>1000 ml-1) were still present the following month. Likewise, for the blooms in 2005 and 2006, abundances $>1000 \mathrm{ml}^{-1}$ were observed on at least 2 dates (Table 1), indicating that monthly sampling intervals should have given an indication of a February or early March bloom. The integrated daily PAR averaged over the week prior to the March 2007 sampling date was also low (27.8 versus $42-44 \mathrm{M} \mathrm{m}^{-1} \mathrm{~d}^{-1}$ prior to blooms in 2005 and 2006). Thus it seems unlikely that there was an early, unobserved bloom. Average air temperature during the week prior to blooms in 2007 was approximately $10^{\circ} \mathrm{C}$ cooler than in 2005 and 2006 (Hargreaves 2007) as were water temperatures (Table 1), and average daily irradiance was considerably lower (Fig. 2). We speculate that cooler temperatures and reduced insolation in March and April 2007 inhibited the initiation of a bloom that year.
Our experiments, and others, show that temperature affects growth and feeding rates in Dinobryon as in many other protists (Caron et al. 1986, Bird \& Kalff 1987, Jones \& Rees 1994, Weisse et al. 2002). Field data indicate that highest abundances of Dinobryon are often found at temperatures between 9 and $18^{\circ} \mathrm{C}$ (Fig. 4), and the tendency of Dinobryon to migrate to an intermediate temperature when light and nutrient levels were constant (Clegg et al. 2003, Heinze \& Sanders 2009) suggests that there may be a directed movement toward temperatures where growth rates are high. Nutrient concentrations were not reported for the studies plotted in Fig. 4; however, Dinobryon, like many chrysophytes, are considered good competitors at low nutrient levels, and can gain nutrients from bacterivory, so migration to depths in search of high nutrient levels seems unlikely. It is more likely that high nutrient levels would put Dinobryon at a competitive disadvantage (Sandgren 1988). Thus, while light, nutrients, and predation likely affect the distribution of Dinobryon, the field and laboratory data strongly suggest that temperature plays a major role driving depth and seasonal distribution of Dinobryon species.

Acknowledgements. This research was supported in part by funding from the National Science Foundation (DEB0210972) and from an award to A.W.H. from the Watres Student Research Fund (Lacawac Sanctuary). We thank T. Heinze, J. Oleshevski, W. Stichter, and S. Connelly for assistance in the field, C. Williamson for use of the BIC radiometer, and B. Hargreaves for weather station data, including solar radiation and air temperature.

\section{LITERATURE CITED}

Berninger UG, Caron DA, Sanders RW (1992) Mixotrophic algae in three ice-covered lakes of the Pocono Mountains, USA. Freshw Biol 28:263-272

Bird DF, Kalff J (1986) Bacterial grazing by planktonic lake algae. Science 231:493-495

Bird DF, Kalff J (1987) Algal phagotrophy: regulating factors and importance relative to photosynthesis in Dinobryon (Chrysophyceae). Limnol Oceanogr 32:277-284

Butterwick C, Heaney SI, Talling JF (2005) Diversity in the influence of temperature on the growth rates of freshwater algae, and its ecological relevance. Freshw Biol 50: 291-300

Caron DA, Goldman JC, Dennett MR (1986) Effect of temperature on growth, respiration, and nutrient regeneration by an omnivorous microflagellate. Appl Environ Microbiol 52:1340-1347

> Caron DA, Sanders RW, Lim EL, Marrase C and others (1993) Light-dependent phagotrophy in the freshwater mixotrophic chrysophyte Dinobryon cylindricum. Microb Ecol 25:93-111

> Clegg MR, Maberly SC, Jones RI (2003) Behavioral response 
of freshwater phytoplanktonic flagellates to a temperature gradient. Eur J Phycol 38:195-203

Dokulil MT, Skolaut C (1991) Aspects of phytoplankton seasonal succession in Mondsee, Austria, with particular reference to the ecology of Dinobryon Ehrenb. Verh Int Verein Limnol 24:968-973

Eloranta P (1989) On the ecology of the genus Dinobryon in Finnish lakes. Nova Hedwigia Beih 95:99-109

Flint EA (1938) A preliminary study of the phytoplankton in Lake Sarah (New Zealand). J Ecol 26:353-358

Hargreaves BR (2007) Pocono Plateau Lake \& Weather Monitoring. Available at www.lehigh.edu/ brh0/pocono_mon (accessed June 2, 2013)

Heinze AW, Sanders RW (2009) Novel temperature gradient incubator to study the effects of temperature on motile aquatic organisms. Limnol Oceanogr Methods 7 : 216-221

Hitchman RB, Jones HLJ (2000) The role of mixotrophic protists in the population dynamics of the microbial food web in small artificial pond. Freshw Biol 43:231-241

Jones RI, Rees S (1994) Influence of temperature and light on particle ingestion by the freshwater phytoflagellate Dinobryon. Arch Hydrobiol 132:203-211

Kamjunke N, Henrichs T, Gaedke U (2007) Phosphorus gain by bacterivory promotes the mixotrophic flagellate Dinobryon spp. during re-oligotrophication. J Plankton Res 29:39-46

Lehman JT (1976) Ecological and nutritional studies on Dinobryon Ehrenb.: seasonal periodicity and the phosphate toxicity problem. Limnol Oceanogr 21:646-658

Olenina I, Hajdu S, Edler L, Andersson A and others (2006) Biovolumes and size-classes of phytoplankton in the Baltic Sea. HELCOM Baltic Sea Environment Protection Commission, Helsinki

Ostrofsky ML, Duthie H (1975) Primary productivity and phytoplankton of lakes on the Eastern Canadian Shield. Verh Int Verein Limnol 19:732-738

Sanders RW, Porter KG (1990) Bacterivorous flagellates as food resources for the freshwater crustacean zooplankton Daphnia ambigua. Limnol Oceanogr 35:188-191

Sanders RW, Porter KG, Bennett SJ, DeBiase AE (1989) Seasonal patterns of bacterivory by flagellates, ciliates, rotifers, and cladocerans in a freshwater planktonic community. Limnol Oceanogr 34:673-687

Sanders RW, Caron DA, Davidson JM, Dennett MR, Moran DM (2001) Nutrient acquisition and population growth of

Editorial responsibility: Urania Christaki, Wimereux, France a mixotrophic alga in axenic and bacterized cultures. Microb Ecol 42:513-523

Sandgren CD (1988) The ecology of chrysophyte flagellates: their growth and perennation strategies as freshwater phytoplankton. In: Sandgren CD (ed) Growth and reproduction strategies of freshwater phytoplankton. Cambridge University Press, Cambridge, p 9-104

Satchwill T, Watson SB, Dixon E (2007) Odourous algalderived alkenes: differences in stability and treatment responses in drinking water. Water Sci Technol 55:95-102

Sherr EB, Sherr BF (1993) Protistan grazing rates via uptake of fluorescently labeled prey. In: Kemp PF, Sherr BF, Sherr EB, Cole JJ (eds) Handbook of methods in aquatic microbial ecology. Lewis Publishers, Boca Raton, FL, p 695-701

Siver PA, Chock JS (1986) Phytoplankton dynamics in a chrysophycean lake. In: Kristiansen J, Andersen RA (eds) Chrysophytes: aspects and problems. Cambridge University Press, Cambridge, p 165-183

Sommer U, Sommer F, Santer B, Zöllner E and others (2003) Daphnia versus copepod impact on summer phytoplankton: functional compensation at both trophic levels. Oecologia 135:639-647

> Tadonléké RD, Jugnia LB, Sime-Ngando T, Devauz J, Romagoux JC (2002) Food web structure in the recently flooded Sep Reservoir as inferred from phytoplankton population dynamics and living microbial biomass. Microb Ecol 43:67-81

Tappa DW (1965) The dynamics of the association of six limnetic species of Daphnia in Aziscuos Lake, Maine. Ecol Monogr 35:395-423

Veen A (1991) Ecophysiological studies on the phagotrophic phytoflagellate Dinobryon divergens Imhof. PhD dissertation, Universiteit van Amsterdam

Watson SB, Satchwill T, Dixon E, McCauley E (2001) Underice blooms and source-water odour in a nutrient-poor reservoir: biological, ecological and applied perspectives. Freshw Biol 46:1553-1567

> Weisse T, Stadler P, Lindström ES, Kimmance SA, Montagnes DJS (2002) Interactive effect of temperature and food concentration on growth rate: a test case using the small freshwater ciliate Urotricha farcta. Limnol Oceanogr 47:1447-1455

> Williamson CE, Neale PJ, Grad G, Lange HJD, Hargreaves BR (2001) Beneficial and detrimental effects of UV on aquatic organisms: implications of spectral variation. Ecol Appl 11:1843-1857

Submitted: June 10, 2013; Accepted: October 8, 2013 Proofs received from author(s): December 2, 2013 